\title{
Pengaruh Model Pembelajaran Think Talk Write (TTW) Terhadap Sikap Ilmiah Dan Hasil Belajar IPA
}

\author{
Ni Komang Ayu Apriliyani ${ }^{*}$, Nyoman Dantes ${ }^{2}$, Ketut Pudjawan ${ }^{3}$ \\ 1 Jurusan Pendidikan Guru Sekolah Dasar, Fakultas Ilmu Pendidikan, Universitas Pendidikan Ganesha Singaraja, Indonesia \\ 2Jurusan Bimbingan Konseling, Fakultas Ilmu Pendidikan, Universitas Pendidikan Ganesha Singaraja, Indonesia \\ 3Jurusan Teknologi Pendidikan, Fakultas Ilmu Pendidikan, Universitas Pendidikan Ganesha Singaraja, Indonesia
}

\section{ARTICLEIN $\mathrm{F} \mathrm{O}$ \\ Article history: \\ Received 17 May \\ 2018 \\ Received in revised \\ form \\ 12 June 2018 \\ Accepted 17 July \\ 2018 \\ Available online 28 \\ August 2018}

\section{Kata Kunci:}

hasil belajar, sikap

ilmiah, TTW

Keywords:

learning

achievement

scientific attitude,

TTW

pembelajaran model Think Talk Write (TTW) dengan siswa yang mengikuti pembelajaran konvensional $(F=24,285 ; p<0,05)$. Berdasarkan temuan tersebut, dapat disimpulkan bahwa model pembelajaran Think Talk Write berpengaruh positif terhadap sikap ilmiah dan hasil belajar IPA siswa.

\section{A B S T R A C T}

This research aims to determine the differences of Think Talk Write (TTW) learning model toward scientific attitude and science learning achievement. This research is a quasi experiment research using nonequivalent post-test only control group design. The population of this research was the fifth grade students of Gugus VI Klungkung at Klungkung regency in academic year 2017/2018 which are 93 students. The samples are 42 students were taken by using group random sampling techniques. The collection of scientific attitudes data was using non-test method with the questionnaire instrument, while the science learning achievement using test method with the multiple-choice test instrument and student science worksheet, that was analyzed by descriptive statistics and Manova. The results of the research show that: 1) there was differences of scientific attitude between students who are following the Think Talk Write (TTW) learning model with students who are following a conventional learning $\left.\left(F_{\text {value }}=26,678>F_{\text {table }}=4,08\right) ; 2\right)$ there was differences of science learning achievement between students who are following the Think Talk Write (TTW) learning model with students who are following a conventional learning $\left(F_{\text {value }}=33,116>F_{\text {table }}=4,08\right)$; and 3$)$ there was of differences in scientific attitude and science learning achievement between students who are following the Think Talk Write (TTW) learning model with students who are following a conventional learning $(F=24,285 ; p<0,05)$. Based on the findings above, it can be concluded that Think Talk Write (TTW) learning model had positive effect toward scientific attitude and science learning achievement.

Copyright (C) Universitas Pendidikan Ganesha. All rights reserved.

\footnotetext{
* Corresponding author.

E-mail addresses: ayuapriliyani56@yahoo.com (Ni Komang Ayu Apriliyani)
} 



\section{Pendahuluan}

Pendidikan mempunyai peranan penting dalam memajukan dan mencerdaskan kehidupan bangsa sekaligus sarana membangun manusia seutuhnya. Selain itu, pendidikan dijadikan pioner utama dalam penyiapan sumber daya manusia sebagai syarat mewujudkan pembangunan nasional sehingga pendidikan telah menjadi suatu kebutuhan bagi seseorang dalam mengembangkan potensi yang dimiliki. Dengan demikian, pendidikan tidak hanya menekankan pada pengetahuan yang dimiliki namun juga pembentukan sikap dan karakter siswa.

Menurut Susanto (2014:165), "salah satu masalah pendidikan yang dihadapi dunia pendidikan saat ini adalah lemahnya pelaksanaan proses pembelajaran yang diterapkan guru di sekolah". Dalam proses pembelajaran terjadi aktivitas belajar mengajar yang di dalamnya terdapat interaksi antara guru dan siswa. Apabila interaksi yang terjadi berjalan dengan baik maka tujuan pembelajaran dapat tercapai sesuai dengan harapan. Lemahnya pelaksanaan proses pembelajaran ini juga terjadi pada mata pelajaran IPA.

Berdasarkan survei Trend in International Mathematics and Science Study (TIMSS) tahun 2015 yang mengukur capaian Matematika dan IPA siswa SD/MI pada studi Internasional yang menempatkan Indonesia diurutan bawah yakni urutan 45 dari 50 negara pada bidang matematika dan urutan 45 dari 48 negara pada bidang Sains atau IPA dengan skor 397 (Kemdikbud, 2016). Hal ini memprihantinkan, mengingat pelajaran IPA merupakan salah satu mata pelajaran pokok yang diajarkan pada setiap jenjang pendidikan mulai dari jenjang sekolah dasar sampai perguruan tinggi.

Trianto (2010:136) menyatakan bahwa "IPA adalah suatu kumpulan pengetahuan tersusun secara sistematik, penerapannya secara umum terbatas pada gejala-gejala alam melalui metode ilmiah serta menuntut sikap ilmiah seperti rasa ingin tahu, terbuka, jujur, dan sebagainya. Secara umum, "IPA dapat dibagi menjadi tiga yaitu IPA sebagai produk, proses dan sikap" (Riastini, 2016:4). Jika dicermati dalam pembelajaran IPA idealnya harus ditempuh melalui langkah-langkah pembelajaran sains (proses IPA), sehingga dapat menghasilkan suatu pengetahuan berupa fakta, prinsip, konsep, dan teori (produk IPA), maka kedua hal tersebut harus didukung dengan sikap ilmiah. Hal ini juga sesuai dengan tujuan pemberian pendidikan IPA di sekolah dasar yaitu agar siswa mampu menguasai konsep IPA dan keterkaitannya serta mampu mengembangkan sikap ilmiah untuk memecahkan masalah-masalah yang dihadapi. Dari paparan tersebut tentunya, diharapkan pembelajaran IPA di SD dapat mengacu pada tiga aspek IPA yaitu proses, produk, dan sikap yang berdampak pula pada hasil belajar IPA.

Menurut Marjono (dalam Susanto, 2014:167) menyatakan "pada jenjang sekolah dasar hal yang harus diutamakan adalah bagaimana mengembangkan rasa ingin tahu dan daya berpikir kritis mereka pada suatu masalah". Artinya proses pembelajaran IPA diharapkan dapat merangsang keingintahuan dan sikap berpikir kritis siswa sehingga siswa akan lebih memahami materi pembelajaran dengan belajar secara mandiri dalam memecahkan suatu masalah dan menemukan suatu konsep. Melalui pengalaman belajar siswa inilah dapat mendorong dan menumbuhkembangkan sikap ilmiah yang dimiliki siswa karena sikap ini terbentuk dari pengalaman melalui proses belajar.

Bundu (2006:13) menyatakan "sikap ilmiah atau sikap sains merupakan sikap yang dimiliki para ilmuwan dalam mencari dan mengembangkan pengetahuan baru, misalnya obyektif terhadap fakta, hatihati, bertanggung jawab, berhati terbuka, selalu ingin meneliti, dan sebagainya". Sikap ilmiah yang dimiliki siswa akan memengaruhi keinginan siswa untuk terlibat dalam kegiatan pembelajaran dan cara siswa dalam merespon objek, orang lain atau peristiwa yang ada di sekitarnya sehingga dengan keterlibatan siswa secara aktif dalam proses pembelajaran dapat bertampak pada peningkatan hasil belajar siswa. Apabila seseorang telah belajar pasti terjadi perubahan tingkah laku pada orang tersebut, misalnya dari tidak tahu menjadi tahu, dari tidak mengerti menjadi mengerti (Hamalik, 2006).

Namun, kenyataannya sering kali guru mengalami kesulitan berkaitan dengan pemahaman, penyampaian materi ajar pada siswa dan membentuk sikap ilmiah siswa. Berdasarkan hasil observasi dan wawancara di SD Gugus VI Kecamatan Klungkung Kabupaten Klungkung khususnya di kelas V, diketahui bahwa pembelajaran masih berpusat pada guru, sebagian besar masih menggunakan metode atau model pembelajaran secara berulang seperti metode ceramah dan penugasan, antusiasme siswa dalam belajar kurang, terlihat dari sedikitnya perhatian siswa saat guru menjelaskan dan memberikan pertanyaan, partisipasi siswa dalam proses pembelajaran masih rendah, banyak siswa yang masih bercanda dan kurang fokus dalam belajar, siswa mengalami kesulitan dalam menyampaikan pendapat/ide yang dimiliki, dan cenderung kurang percaya diri sehingga sulit mengungkapkan pendapatnya.

Selain itu, dilihat dari hasil belajar yang diperoleh siswa masih belum memuaskan khususnya pada mata pelajaran IPA. Pernyataan ini diperkuat dengan pencatatan dokumen yang diperoleh berupa nilai ulangan akhir semester I siswa kelas V, yakni sebanyak 61,29\% dari jumlah keseluruhan siswa kelas V di 
SD Gugus VI Kecamatan Klungkung Kabupaten Klungkung belum memenuhi KKM yang ditetapkan di sekolah.

Aktivitas pembelajaran yang dilakukan secara berulang sehingga bersifat konvensional, selain itu kurang adanya variasi dalam proses pembelajaran. Seperti halnya penugasan yang diberikan secara individu yang mengakibatkan siswa menjadi cepat bosan dan kurang adanya interaksi antar siswa. Selain itu, siswa jarang melakukan kegiatan diskusi secara berkelompok untuk melatih siswa memecahkan suatu permasalahan, mengingat waktu pembelajaran IPA yang terbatas. Padahal melalui kegiatan diskusi siswa dapat mengeksplorasi materi yang dipelajari serta menjalin interaksi antar siswa (kerjasama) sehingga sikap ilmiah dapat dikembangkan. Jadi aktivitas belajar siswa ini juga dapat memengaruhi hasil belajar siswa karena kurangnya pengalaman belajar yang dimiliki.

Salah satu upaya yang dapat dilakukan adalah dengan menerapkan model pembelajaran Think Talk Write (TTW). Huinker dan Laughlin (dalam Shoimin, 2014:212) menyebutkan "aktivitas yang dapat dilakukan untuk menumbuhkembangkan kemampuan pemahaman konsep dan komunikasi peserta didik adalah dengan penerapan model Think Talk Write (TTW)".

Dalam pembelajaran TTW, siswa akan lebih banyak bekerja dengan teman atau dalam kelompok (kooperatif). Siswa diarahkan untuk berpikir tentang suatu permasalahan yang diberikan, mendiskusikan permasalahan dengan teman sekelompoknya, sehingga memperoleh jawaban atau solusi pemecahan masalah, dan menuliskannya ke dalam catatan (lembar jawaban) dan melaporkan hasil diskusi atau presentasi di depan kelas. Dengan penerapan model ini, dapat mengembangkan sikap ilmiah siswa dalam menghadapi permasalahan yang diberikan seperti saat melakukan kegiatan diskusi kelompok. Hal ini sesuai dengan pendapat Susanto (2014:169) menyatakan, "sikap ilmiah siswa dapat dikembangkan melalui kegiatan diskusi, percobaan, simulasi, dan kegiatan proyek di lapangan".

Siswa dilatih untuk mengaitkan pembelajaran dengan masalah-masalah yang ada di lingkungan sekitar siswa sehingga membiasakan siswa untuk berpikir, berbicara dan mengeluarkan pendapat serta menuliskan apa yang dipikirkannya. Melalui latihan-latihan tersebut, dapat merangsang adanya sikap ilmiah siswa selama pembelajaran, seperti menumbuhkan rasa ingin tahu, berpikir kritis, mampu bekerjasama dan berpikiran terbuka dalam berdiskusi. Dengan adanya pengalaman dan aktivitas belajar yang tinggi dari siswa, tidak hanya berdampak pada sikap ilmiah yang dimiliki tetapi pada peningkatan hasil belajar IPA.

Penelitian ini dikuatkan oleh penelitian sebelumnya yang dilakukan oleh Putri Dewi Andriani (2016) menyatakan penelitian ini menunjukan bahwa penerapan model pembelajaran Think Talk Write (TTW) dapat meningkatkan kemampuan menyelesaikan soal cerita pecahan pada siswa kelas IV SD Negeri Karangasem I Surakarta tahun ajaran 2015/2016. Setya Ratna Dianuri (2016) Menunjukkan bahwa terdapat perbedaan kemampuan menulis cerita siswa yang diajar dengan menggunakan model pembelajaran Think Talk Write (TTW) dan model pembelajaran Student Teams Achievment Division (STAD). Dian Ayu Dewayani (2016) menyatakan ada pengaruh yang signifikan model pembelajaran think talk write (TTW) terhadap hasil belajar pemecahan soal cerita bilangan bulat matematika siswa tunarungu kelas IV di SLB-B Dharma Wanita Sidoarjo $=5 \%$ 0,05 $>$ U tabel= 0,021 Ut) sehingga Ho ditolak dan Ha diterima. Hartanto (2017) menyakan bahwa model pembelajaran TTW dengan bantuan LKS sangat efektif digunakan untuk meningkatkan aktivitas dan hasil belajar siswa kelas VII.A SMP Negeri 2 Rantau Panjang. Resi Irmayati (2015) menyatakan bahwa ada pengaruh yang signifikan dan besarnya taraf signifikansi pengaruh penerapan model Think Talk Write (TTW) adalah sebesar 0,51 yang berarti cukup

Adapun tujuan dari penelitian ini adalah: 1) untuk mengetahui perbedaan sikap ilmiah antara siswa yang mengikuti pembelajaran model Think Talk Write (TTW) dengan siswa yang mengikuti pembelajaran konvensional, 2) untuk mengetahui perbedaan hasil belajar IPA siswa yang mengikuti pembelajaran model Think Talk Write (TTW) dengan siswa yang mengikuti pembelajaran konvensional, 3) untuk mengetahui perbedaan simultan sikap ilmiah dan hasil belajar IPA antara siswa yang mengikuti pembelajaran model Think Talk Write (TTW) dengan pembelajaran konvensional.

\section{Metode}

Penelitian ini merupakan jenis penelitian eksperimen semu (quasi experiment), dengan rancangan eksperimen yang digunakan nonequivalent post-test only control group design. Populasi penelitian ini adalah seluruh siswa kelas V SD Gugus VI Kecamatan Klungkung Kabupaten Klungkung tahun pelajaran 2017/2018 yang berjumlah 93 orang, sehingga sampel dalam penelitian ini dipilih dengan teknik group random sampling. Sebelum menentukan sampel penelitian, populasi diuji kesetaraannya berdasarkan nilai ulangan akhir semester I mata pelajaran IPA dengan uji Anava satu jalur. Setelah dilakukan uji kesetaraan, 
selanjutnya dilakukan pengundian sampel, sehingga ditetapkan SDN 3 Selat yang berjumlah 22 orang sebagai kelompok eksperimen, dan SDN 3 Tegak yang berjumlah 20 orang sebagai kelompok kontrol.

Data dalam penelitian ini ada dua yaitu sikap ilmiah dan hasil belajar IPA. Data mengenai sikap ilmiah dikumpulkan menggunakan lembar kuesioner yang diukur dengan skala Lickert yang terdiri dari lima pilihan jawaban yang telah disediakan (1-5). Sedangkan data hasil belajar IPA dikumpulkan menggunakan tes objektif pilihan ganda dan pembobotan nilai LKS.

Tes objektif pilihan ganda memuat empat alternatif jawaban yang akan dipilih siswa. Setiap jawaban diberikan bobot 1 untuk jawaban benar dan 0 untuk jawaban salah. Hasil belajar IPA juga diukur dengan menggunakan LKS sebagai penunjang pelaksanaan pembelajaran pada kelompok yang menggunakan model pembelajaran Think Talk Write (TTW). Skor pada soal LKS akan digunakan sebagai hasil dari proses pembelajaran untuk mengetahui sejauh mana model pembelajaran Think Talk Write (TTW) dapat meningkatkan hasil belajar IPA siswa. Selanjutnya, skor yang diperoleh pada masing-masing soal objektif dan soal LKS diberikan bobot yakni 60\% untuk skor pengerjaan LKS dan 40\% untuk skor tes pilihan ganda. Hasil dari pembobotan soal objektif dan soal pengerjaan LKS dijumlahkan sehingga menghasilkan skor akhir.

Pada penelitian ini penggunaan instrumen sesuai dengan jenis data yang dicari. Sebelum instrumen digunakan terlebih dahulu dilakukan expert judgment oleh dua orang pakar guna mendapatkan kualitas tes yang baik.

Setelah dilakukan expert judgment maka instrumen akan diujicobakan ke lapangan untuk mendapatkan gambaran mengenai dapat tidaknya instrumen tersebut digunakan sebagai instrumen penelitian. Pengujian instrumen sikap ilmiah dilakukan dengan uji validitas isi kuesioner oleh pakar, uji validitas internal konsistensi butir dengan teknik korelasi product moment, dan uji reliabilitas kuesioner dengan menggunakan rumus Alpha-Cronbach. Sedangkan untuk pengujian instrumen tes hasil belajar IPA dilakukan dengan pengujian validitas isi tes oleh pakar, uji validitas butir tes dengan rumus korelasi point biserial, uji reliabilitas dengan rumus KR-20, uji daya beda butir tes, uji tingkat kesukaran butir soal, dan uji efektivitas pengecoh. Berdasarkan hasil pengujian instrumen diperoleh 30 butir pernyataan sikap ilmiah dan 30 butir tes hasil belajar IPA yang dapat digunakan sebagai instrumen penelitian.

Data hasil penelitian yang telah dikumpulkan kemudian dianalisis secara bertahap, yaitu deskripsi data, uji prasyarat, dan uji hipotesis. Pengujian hipotesis 1 dan hipotesis 2 dilakukan dengan uji Anava satu jalur, sedangkan pengujian hipotesis 3 dilakukan dengan uji Manova (Multivariate Analysis of Varians) dengan bantuan program SPSS-17.00 for windows.

\section{Hasil dan Pembahasan}

Berdasarkan analisis data yang dilakukan terhadap sikap ilmiah dan hasil belajar IPA, diperoleh hasil seperti yang tersaji pada Tabel 1 berikut.

Tabel 1. Rekapitulasi Hasil Perhitungan Skor Sikap Ilmiah dan Hasil Belajar IPA

\begin{tabular}{lcccc}
\hline \multicolumn{1}{r}{ Variabel } & \multicolumn{4}{c}{} \\
\cline { 2 - 5 } Statistik & Y1 & Y2 & Y1 & Y2 \\
Jumlah Responden & 22 & 22 & 20 & 20 \\
Mean & 87,36 & 83,68 & 75,40 & 71,50 \\
Median & 88,50 & 84,70 & 74,07 & 70,75 \\
Modus & 90,50 & 86,83 & 73,21 & 70,50 \\
Varians & 42,190 & 34,147 & 66,537 & 61,608 \\
Standar Deviasi & 6,495 & 5,844 & 8,157 & 7,849 \\
Skor Maksimun & 97 & 90 & 91 & 87 \\
Skor Minimum & 74 & 70 & 60 & 57 \\
Rentangan & 23 & 20 & 31 & 30 \\
\hline
\end{tabular}

Keterangan :

$\mathrm{A}_{1} \mathrm{Y}_{1} \quad$ : skor sikap ilmiah siswa yang mengikuti pembelajaran dengan model Think Talk Write (TTW).

$\mathrm{A}_{1} \mathrm{Y}_{2} \quad$ :skor hasil belajar IPA siswa yang mengikuti pembelajaran dengan model Think Talk Write (TTW).

$\mathrm{A}_{2} \mathrm{Y}_{1} \quad$ :skor sikap ilmiah siswa yang mengikuti pembelajaran konvensional.

$\mathrm{A}_{2} \mathrm{Y}_{2} \quad$ :skor hasil belajar IPA siswa yang mengikuti pembelajaran konvensional. 
Berdasarkan Tabel 1, diketahui bahwa: (1) rata-rata skor sikap ilmiah siswa yang mengikuti pembelajaran model Think Talk Write (TTW) adalah 87,36 dengan kategori sangat tinggi, sedangkan ratarata skor sikap ilmiah siswa yang mengikuti pembelajaran konvensional memiliki rata-rata skor sebesar 75,40 berada pada kategori tinggi. Secara deskriptif, dapat dijelaskan bahwa kelompok siswa yang mengikuti pembelajaran model Think Talk Write (TTW) memiliki sikap ilmiah yang lebih baik dibandingkan dengan kelompok siswa yang mengikuti pembelajaran konvensional. (2) rata-rata skor hasil belajar IPA siswa yang mengikuti pembelajaran model Think Talk Write (TTW) sebesar 83,68 termasuk kategori sangat tinggi, sedangkan rata-rata skor hasil belajar IPA siswa yang mengikuti pembelajaran konvensional memiliki rata-rata skor lebih kecil yakni 71,50 yang berada pada kategori tinggi. Secara deskriptif, dapat dijelaskan bahwa kelompok siswa yang mengikuti pembelajaran model Think Talk Write (TTW) memiliki hasil belajar IPA yang lebih baik dibandingkan dengan kelompok siswa yang mengikuti pembelajaran konvensional. Hal ini mengindikasikan bahwa model pembelajaran Think Talk Write (TTW) lebih unggul daripada pembelajaran konvensional untuk meningkatkan sikap ilmiah dan hasil belajar IPA siswa.

Sebelum dilakukan pengujian hipotesis, terlebih dahulu dilakukan uji prasyarat analisis yaitu uji normalitas sebaran data, uji homogenitas varians, dan uji korelasi variabel terikat. Hasil uji normalitas sebaran data masing-masing variabel menunjukkan bahwa $\chi_{\text {hitung }}^{2}<\chi_{\text {tabel }}^{2}$, sehingga data berdistribusi normal. Selanjutnya uji homogenitas varians dilakukan terhadap data sikap ilmiah dan hasil belajar IPA siswa secara terpisah maupun secara bersama-sama. Hasil uji homogenitas secara terpisah dapat menggunakan uji $\mathrm{F}$, sehingga diperoleh $\mathrm{F}_{\text {hitung }}<\mathrm{F}_{\text {tabel. }}$ Sedangkan uji homogenitas varians secara bersamasama dapat dilihat dari hasil uji Box' $M$, memiliki signifikansi lebih besar dari 0,05. Berdasarkan hal tersebut, dapat disimpulkan bahwa hasil analisis uji homogenitas varians secara terpisah maupun bersama-sama menunjukkan bahwa matriks varian-kovarians terhadap sikap ilmiah dan hasil belajar IPA siswa adalah homogen.

Hasil uji korelasi variabel terikat menunjukkan bahwa data sikap ilmiah dan hasil belajar IPA siswa yang mengikuti pembelajaran model Think Talk Write (TTW) memiliki harga $r_{\text {hitung }}=0,1631<r_{\text {tabel }}=$ 0,4227 sedangkan data sikap ilmiah dan hasil belajar IPA siswa yang mengikuti pembelajaran konvensional memiliki harga $r_{\text {hitung }}=0,2278<r_{\text {tabel }}=0,4438$ pada taraf signifikansi 5\%, sehingga dapat ditarik kesimpulan bahwa data sikap ilmiah dan hasil belajar siswa yang mengikuti pemelajaran model Think Talk Write (TTW) maupun pembelajaran konvensional tidak berkorelasi.

Pengujian hipotesis 1 dan 2 menggunakan uji Anava satu jalur, sedangkan pengujian hipotesis ke-3 menggunakan uji Manova. Berikut hasil pengujian hipotesis 1 dengan menggunakan uji Anava satu jalur, dapat dilihat pada Tabel 2.

Tabel 2. Hasil Uji Hipotesis 1 Data Sikap Ilmiah Siswa Kelas V

\begin{tabular}{ccccccc}
\hline Sumber Variasi & $\mathrm{JK}$ & $\mathrm{db}$ & $\mathrm{RJK}$ & $\mathrm{F}$ hitung & \multicolumn{2}{c}{$\mathrm{F}_{\text {tabel }}$ pada Taraf Sig. } \\
\cline { 5 - 7 } & & & & $5 \%$ & $1 \%$ \\
Antar & 1434,086 & 1 & 1434,086 & 26,678 & 4,08 & 7,31 \\
Dalam (error) & 2150,2 & 40 & 53,755 & -- & -- & -- \\
Total & 3584,286 & -- & -- & -- & -- & -- \\
\hline
\end{tabular}

Dari Tabel 2 tersebut dapat diketahui bahwa sikap ilmiah siswa yang mengikuti pembelajaran model Think Talk Write $($ TTW $)$ dan pembelajaran konvensional menunjukkan harga $\mathrm{F}_{\text {hitung }}=26,678>\mathrm{F}_{\text {tabel }}$ = 4,08 pada taraf signifikansi 5\%. Hal ini berarti $\mathrm{H}_{\mathrm{o}}$ ditolak dan $\mathrm{H}_{1}$ yang menyatakan "terdapat perbedaan sikap ilmiah antara siswa yang mengikuti pembelajaran model Think Talk Write (TTW) dengan siswa yang mengikuti pembelajaran konvensional pada siswa kelas V SD Gugus VI Kecamatan Klungkung Kabupaten Klungkung tahun pelajaran 2017/2018" diterima.

Tabel 3. Hasil Uji Hipotesis 2 Data Hasil Belajar IPA Siswa Kelas V

\begin{tabular}{ccccccc}
\hline Sumber Variasi & $\mathrm{JK}$ & $\mathrm{db}$ & $\mathrm{RJK}$ & $\mathrm{F}$ hitung & \multicolumn{2}{c}{$\mathrm{F}_{\text {tabel }}$ pada Taraf Sig. } \\
\cline { 3 - 7 } & & & & $5 \%$ & $1 \%$ \\
Antar & 1562,764 & 1 & 1562,764 & 33,116 & 4,08 & 7,31 \\
Dalam (error) & 1887,641 & 40 & 47,191 & -- & -- & -- \\
Total & 3450,405 & -- & -- & -- & -- & -- \\
\hline
\end{tabular}


Berdasarkan Tabel 3, dapat dikehui bahwa hasil belajar IPA siswa yang mengikuti pembelajaran model Think Talk Write (TTW) dan siswa yang mengikuti pembelajaran konvensional menunjukkan harga $\mathrm{F}_{\text {hitung }}=33,116>\mathrm{F}_{\text {tabel }}=4,08$ pada taraf signifikansi 5\%. Hal ini berarti $\mathrm{H}_{\mathrm{o}}$ ditolak dan $\mathrm{H}_{1}$ yang menyatakan "terdapat perbedaan hasil belajar IPA antara siswa yang mengikuti pembelajatan model Think Talk Write (TTW) dengan siswa yang mengikuti pembelajaran konvensional pada siswa kelas V SD Gugus VI Kecamatan Klungkung Kabupaten Klungkung tahun pelajaran 2017/2018" diterima. Hasil uji hipotesis 3 dengan uji Manova dapat dilihat dari analisis Pillai's Trace, Wilk's Lamda, Hotelling's Trance, Roy's Largest Root dapat dilihat pada Tabel 4 berikut.

Tabel 4. Hasil Analisis Sikap Ilmiah dan Hasil Belajar IPA dengan Uji Manova

\begin{tabular}{|c|c|c|c|c|c|c|}
\hline Effect & & Value & $F$ & Hypothesis $d f$ & Error $d f$ & Sig. \\
\hline \multirow[t]{8}{*}{ Intercept } & Pillai's Trace & .995 & $4231.493^{a}$ & 2.000 & 39.000 & $<$ \\
\hline & & & & & & 0,05 \\
\hline & Wilks' Lambda & .005 & $4231.493^{a}$ & 2.000 & 39.000 & $<$ \\
\hline & & & & & & 0,05 \\
\hline & Hotelling's Trace & 217.000 & $4231.493^{a}$ & 2.000 & 39.000 & $<$ \\
\hline & & & & & & 0,05 \\
\hline & Roy's Largest Root & 217.000 & $4231.493^{a}$ & 2.000 & 39.000 & $<$ \\
\hline & & & & & & 0,05 \\
\hline \multirow[t]{7}{*}{$K$} & Pillai's Trace & .555 & $24.285^{\mathrm{a}}$ & 2.000 & 39.000 & $<$ \\
\hline & & & & & & 0,05 \\
\hline & Wilks' Lambda & .445 & $24.285^{\mathrm{a}}$ & 2.000 & 39.000 & $<$ \\
\hline & & & & & & 0,05 \\
\hline & Hotelling's Trace & 1.245 & $24.285^{\mathrm{a}}$ & 2.000 & 39.000 & $<$ \\
\hline & Rov's Laraest Root & 1245 & $24285 a$ & 2000 & 20000 & 0,05 \\
\hline & & & & & & 0,05 \\
\hline \multicolumn{7}{|c|}{ a. Exact statistic } \\
\hline \multicolumn{7}{|c|}{ b. Design: Intercept $+K$} \\
\hline
\end{tabular}

Berdasarkan hasil analisis pada Tabel 2, nilai F dari Pillai's Trace, Wilks' Lamda, Hotelling's Trance, dan Roy's Largest Root adalah 24,285 seluruhnya memiliki signifikansi < 0,05, sehingga $\mathrm{H}_{\mathrm{o}}$ ditolak dan $\mathrm{H}_{1}$ yang menyatakan "terdapat perbedaan sikap ilmiah antara siswa yang mengikuti pembelajatan model Think Talk Write (TTW) dengan siswa yang mengikuti pembelajaran konvensional pada siswa kelas V SD Gugus VI Kecamatan Klungkung Kabupaten Klungkung tahun pelajaran 2017/2018" diterima.

Hasil analisis hipotesis 1 dalam penelitian ini menunjukkan nilai $F_{\text {hitung }}=26,678$ sedangkan $F_{\text {tabel }}$ pada taraf signifikansi $5 \%$ adalah 4,08, maka $F_{\text {hitung }}$ lebih besar dari $F_{\text {tabel }}\left(F_{\text {hitung }}=26,678>F_{\text {tabel }}=4,08\right)$, sehingga $\mathrm{H}_{0}$ ditolak dan $\mathrm{H}_{1}$ yang menyatakan bahwa "terdapat perbedaan sikap ilmiah antara siswa yang mengikuti model pembelajaran Think Talk Write (TTW) dengan siswa yang mengikuti pembelajaran konvensional pada siswa kelas V SD Gugus VI Kecamatan Klungkung Kabupaten Klungkung tahun pelajaran 2017/2018" diterima. Hasil ini diperkuat dengan rata-rata skor sikap ilmiah siswa yang mengikuti pembelajaran model Think Talk Write (TTW) yaitu 87,36 yang lebih tinggi dari skor rata-rata siswa yang mengikuti pembelajaran konvensional yaitu 75,40. Perbedaan ini disebabkan karena pada kelompok eksperimen diberikan perlakuan yaitu menggunakan model pembelajaran Think Talk Write (TTW) dalam proses pembelajaran.

Menurut Shoimin (2014) yang menyatakan model Think Talk Write, (1) dapat mengembangkan pemecahan yang bermakna dalam memahami materi ajar, (2) dengan memberikan soal open ended dapat mengembangkan keterampilan berpikir kritis dan kreatif siswa, (3) dengan berinteraksi dan berdiskusi dengan kelompok melibatkan siswa secara aktif dalam belajar, (4) membiasakan siswa berpikir dan berkomunikasi dengan teman, guru, bahkan dengan diri mereka sendiri. Menurut Silver dan Smith (dalam Huda, 2014:219) menyatakan "peranan guru dalam pelaksanan model Think Talk Write (TTW) adalah mengajukan dan menyediakan tugas, mendorong dan menyimak ide-ide yang dikemukakan siswa, memberi pertimbangan dalam diskusi, menilai dan mendorong siswa untuk berpartisifasi secara aktif".

Dengan demikian, pembelajaran yang menggunakan model Think Talk Write (TTW) dapat mengubah pembelajaran yang awalnya berpusat pada guru menjadi berpusat pada siswa. Siswa menjadi lebih aktif dalam proses pembelajaran. Siswa diajak berpikir secara langsung menemukan konsep-konsep pembelajaran dan berinteraksi dengan temannya, sehingga siswa lebih aktif dan mudah dalam memahami 
konsep yang diberikan, sehingga dapat berdampak pada peningkatan sikap ilmiah siswa. Temuan dalam penelitian ini sejalan dengan hasil penelitian yang dilakukan oleh Mitasasrini (2015) yang menunjukkan bahwa model pembelajaran Think Talk Write (TTW) dapat meningkatkan sikap ilmiah siswa, peningkatan tersebut terjadi secara bertahap sesuai penerapan model pembelajaran Think Talk Write (TTW).

Berdasarkan hasil analisis dan temuan dalam penelitian lain yang sesuai dengan penelitian ini dapat disimpulkan bahwa terdapat perbedaan sikap ilmiah siswa yang mengikuti pembelajaran model Think Talk Write (TTW) dengan siswa yang mengikuti pembelajaran konvensional, sehingga model Think Talk Write (TTW) berpengaruh signifikan terhadap sikap ilmiah siswa.

Hasil analisis hipotesis 2 dalam penelitian ini menunjukkan nilai $F_{\text {hitung }}=33,116$ sedangkan $F_{\text {tabel }}$ pada taraf signifikansi 5\% adalah 4,08, maka $\mathrm{F}_{\text {hitung }}$ lebih besar dari $\mathrm{F}_{\text {tabel }}\left(\mathrm{F}_{\text {hitung }}=33,116>\mathrm{F}_{\text {tabel }}=4,08\right)$, sehingga $\mathrm{H}_{0}$ ditolak dan $\mathrm{H}_{1}$ diterima yang dapat ditarik kesimpulan bahwa "terdapat perbedaan hasil belajar IPA antara siswa yang mengikuti model pembelajaran Think Talk Write (TTW) dengan siswa yang mengikuti pembelajaran konvensional pada siswa kelas V SD Gugus VI Kecamatan Klungkung Kabupaten Klungkung tahun pelajaran 2017/2018".

Hal ini diperkuat dengan rata-rata skor hasil belajar IPA siswa yang mengikuti model pembelajaran Think Talk Write (TTW) yaitu 83,68 lebih tinggi dibandingkan dengan siswa yang mengikuti pembelajaran konvensional yang hanya memperoleh rata-rata 71,50. Melalui model pembelajaran Think Talk Write (TTW), siswa diajak berpikir secara langsung menemukan konsep-konsep pembelajaran dan berinteraksi dengan temannya, sehingga siswa lebih aktif dan mudah dalam memahami konsep yang diberikan. Apabila siswa aktif dan paham terhadap materi atau konsep pembelajaran, hasil belajar siswa pun dapat meningkat.

Pada tahap pertama dalam proses pembelajaran terdapat kegiatan berpikir, dengan menggunakan bahasanya sendiri. Cara yang tepat untuk meningkatkan kemampuan berpikir siswa adalah dengan memberikan suatu permasalahan terkait materi pembelajaran kepada siswa. Pada tahap inilah siswa diajak untuk menggali pengetahuan awal yang dimiliki. Pada tahap kedua, terdapat kegiatan berbicara/berkomunikasi yang dilakukan oleh siswa bersama teman kelompoknya. Dalam kegiatan ini, siswa dapat berinteraksi aktif antar kelompok untuk mendengarkan hasil pemikirannya terkait materi yang disajikan.

Pada tahap ketiga, siswa menuliskan ide-ide yang diperolehnya. Menulis dapat membantu merealisasikan salah satu tujuan pembelajaran yaitu pemahaman siswa mengenai materi yang ia pelajari. Dengan menuliskan ide-ide yang diperoleh secara tertulis dapat membantu pemahaman siswa, selain itu melalui kegiatan menulis dapat membantu guru untuk memantau kesalahan siswa seperti miskonsepsi siswa terhadap ide yang sama serta sebagai bukti nyata dari prestasi siswa. Dengan sistem pembelajaran yang berpusat pada siswa, serta tiga tahapan pembelajaran yang dilakukan dapat menumbuhkembangkan kemampuan pemahaman konsep dan komunikasi siswa.

Temuan dalam penelitian ini sejalan dengan hasil penelitian yang dilakukan oleh Armini (2017) yang menunjukkan bahwa terdapat perbedaan yang signifikan hasil belajar IPA antara siswa yang dibelajarkan melalui model pembelajaran Think Talk Write (TTW) dengan siswa yang dibelajarkan dengan pembelajaran konvensional. Selain itu, terdapat juga temuan dari penelitian yang dilakukan Wardhany dan Gufron (2017), yang menyatakan bahwa model pembelajaran Think Talk Write (TTW) efektif dalam meningkatkan hasil belajar khususnya mata pelajaran IPA karena dapat meminimalisir kesulitan yang dihadapi siswa secara tertulis serta membiasakan siswa belajar secara kelompok sehingga dapat meningkatkan keaktifan siswa dalam suatu kegiatan pembelajaran.

Berdasarkan hasil analisis dan temuan dalam penelitian lain yang sesuai dengan penelitian ini dapat disimpulkan bahwa terdapat perbedaan hasil belajar IPA siswa yang mengikuti pembelajaran model Think Talk Write (TTW) dengan siswa yang mengikuti pembelajaran konvensional, sehingga model Think Talk Write (TTW) berpengaruh signifikan terhadap hasil belajar IPA siswa.

Hasil analisis hipotesis 3 dalam penelitian ini menunjukkan nilai $\mathrm{F}$ hitung $=24,285$ untuk Pillai's Trace, Wilks' Lamda, Hotelling's Trance, dan Roy's Largest Root dari pembelajaran model Think Talk Write (TTW) dengan seluruhnya memiliki signifikansi kurang dari 0,05. Hal ini berarti semua nilai Pillai's Trace, Wilks' Lamda, Hotelling's Trance, dan Roy's Largest Root signifikan, sehingga $\mathrm{H}_{0}$ ditolak dan $\mathrm{H}_{1}$ diterima. Berdasarkan hasil analisis uji hipotesis 3 dapat disimpulkan bahwa "terdapat perbedaan secara simultan sikap ilmiah dan hasil belajar IPA antara siswa yang mengikuti model pembelajaran Think Talk Write (TTW) dengan siswa yang mengikuti pembelajaran konvensional pada siswa kelas V SD Gugus VI Kecamatan Klungkung, Kabupaten Klungkung tahun pelajaran 2017/2018", sehingga secara teoritis dapat dikatakan bahwa penggunaan model pembelajaran Think Talk Write (TTW) lebih baik dan efektif untuk meningkatkan sikap ilmiah dan hasil belajar IPA siswa dalam pembelajaran. Hal ini dapat terwujud karena model pembelajaran Think Talk Write (TTW) menekankan pentingnya pemahaman konsep dan komunikasi dalam proses pembelajaran, melalui tahapan-tahapan pembelajaran dalam model ini 
mengarahkan siswa untuk berpikir, berkomunikasi, bekerjasama serta siswa dapat menuliskan ide-ide yang diperoleh secara tertulis sehingga dapat membantu pemahaman siswa.

Dengan pengujian hipotesis yang ketiga terbukti bahwa terdapat perbedaan secara simultan sikap ilmiah dan hasil belajar IPA antara siswa yang mengikuti pembelajaran model Think Talk Write (TTW) dengan siswa yang mengikuti pembelajaran konvensional. Dari uraian di atas dapat disimpulkan bahwa model pembelajaran Think Talk Write (TTW) yang diimplementasikan guru memengaruhi sikap ilmiah dan hasil belajar IPA siswa.

\section{Simpulan dan Saran}

Berdasarkan hasil pengujian hipotesis dan pembahasan, maka simpulan dari penelitian ini adalah sebagai berikut.

Pertama, terdapat perbedaan sikap ilmiah antara siswa yang mengikuti model pembelajaran Think Talk Write (TTW) dengan siswa yang mengikuti pembelajaran konvensional $\left(F_{\text {hitung }}=26,678>F_{\text {tabel }}=4,08\right)$. Rata-rata skor sikap ilmiah siswa yang mengikuti pembelajaran model Think Talk Write (TTW) yaitu 87,36 yang lebih tinggi dari skor rata-rata siswa yang mengikuti pembelajaran konvensional yaitu 75,40. Dengan demikian, pembelajaran model Think Talk Write (TTW) berpengaruh terhadap sikap ilmiah siswa kelas V SD di Gugus VI Kecamatan Klungkung Kabupaten Klungkung tahun pelajaran 2017/2018.

Kedua, terdapat perbedaan hasil belajar IPA antara siswa yang mengikuti model pembelajaran Think Talk Write (TTW) dengan siswa yang mengikuti pembelajaran konvensional $\left(\mathrm{F}_{\text {hitung }}=33,116>\mathrm{F}_{\text {tabel }}=4,08\right)$. Rata-rata skor hasil belajar IPA siswa yang mengikuti pembelajaran model Think Talk Write (TTW) yaitu 83,68 yang lebih tinggi dari skor rata-rata siswa yang mengikuti pembelajaran konvensional yaitu 71,50. Dengan demikian, pembelajaran model Think Talk Write (TTW) berpengaruh terhadap hasil belajar IPA siswa kelas V SD di Gugus VI Kecamatan Klungkung Kabupaten Klungkung tahun pelajaran 2017/2018.

Ketiga, terdapat perbedaan secara simultan sikap ilmiah dan hasil belajar IPA antara siswa yang mengikuti model pembelajaran Think Talk Write (TTW) dengan siswa yang mengikuti pembelajaran konvensional $(\mathrm{F}=24,285 \mathrm{p}<0,05)$. Rata-rata skor sikap sosial dan hasil belajar IPA siswa yang mengikuti pembelajaran model Think Talk Write (TTW) lebih tinggi dari skor ratarata siswa yang mengikuti pembelajaran konvensional.

Berdasarkan temuan-temuan tersebut dapat disimpulkan bahwa terdapat pengaruh implementasi model Think Talk Write (TTW) terhadap sikap ilmiah dan hasil belajar IPA pada siswa kelas V SD di Gugus VI Kecamatan Klungkung Kabupaten Klungkung tahun pelajaran $2017 / 2018$.

Saran digunakan untuk memperbaiki pembelajaran dan memperbaiki kekurangan yang ada dalam penelitian ini. Secara teoretis, penelitian ini dapat memberikan kontribusi mengenai model pembelajaran yang inovatif untuk menunjang proses pembelajaran. Selain itu, terdapat beberapa saran yang diberikan kepada pihak yang terkait yaitu sebagai berikut: 1) dengan diterapkannya model pembelajaran Think Talk Write (TTW), diharapkan siswa bisa lebih aktif dan kreatif dalam berpikir, berbicara, dan menulis, sehingga siswa mampu mengembangkan pengetahuan dan sikap ilmiah pada diri siswa selama proses pembelajaran; 2) penerapan model pembelajaran ini hendaknya diimbangi dengan keaktifan guru memantau proses belajar siswa dan senantiasa memberikan arahan dan bimbingan agar kegiatan pembelajaran dapat berlangsung sesuai dengan tujuan pembelajaran yang dirancang; 3) penerapan model pembelajaran Think Talk Write (TTW) dilakukan sesuai dengan materi dan karakteristik siswa untuk kemajuan mutu pendidikan di sekolah; 4) bagi peneliti lain yang berminat untuk meneliti lebih lanjut penggunaan model Think Talk Write (TTW) terhadap pembelajaran IPA, penelitian ini dapat dijadikan sebagai salah satu referensi pelaksanaan penelitian.

\section{Daftar Rujukan}

Armini, Ni Putu Seni. 2017. "Pengaruh Model Pembelajaran Think Talk Write Terhadap Hasil Belajar IPA pada Siswa Kelas IV SD". e-Jurnal PGSD Universitas Pendidikan Ganesha Mimbar PGSD, Vol: 5, No: 
2. Tersedia pada : https://ejournal.undiksha.ac.id/index.php/JJPGSD/article/view/10671 (diakses tanggal 29 November 2017).

Bundu, Patta. 2006. Penilaian Keterampilan Proses dan Sikap Ilmiah dalam Pembelajaran Sains Sekolah Dasar. Jakarta: Departemen Pendidikan Nasional.

Dian Ayu Dewayani. (2016). Model Pembelajaran Think Talk Write (Ttw) Terhadap Hasil Belajar Pemecahan Soal Cerita Bilangan Bulat Matematika Siswa Tunarungu. Jurnal Pendidikan Khusus Unesa. Vol 1 No.2.

Hamalik, O. 2008. Proses Belajar Mengajar. Jakarta: Bumi Aksara.

Hartanto. (2017). Penerapan Model Pembelajaran Think Talk Write (Ttw) Dengan Bantuan Lembar Kerja Siswa Untuk Meningkatkan Aktivitas Dan Hasil Belajar Ipa Terpadu Siswa Kelas Vii.A Smp Negeri 2 Rantau Panjang. Jurnal Inovasi dan Pembelajaran Fisika. Vol.4 No1

Huda. Miftahul. 2014. Model-Model Pengajaran dan Pembelajaran. Yogyakarta: Pustaka Pelajar

Kemdikbud, 2016. "Mengenai TIMSS Bagaimana Pencapaian Indonesia?". Tersedia pada: http://puspendik.kemdikbud.go.id/seminar/upload/Hasil\%20Seminar\%20Puspendik\%20201 6/TIMSS\%20infographic.pdf (diakses tanggal 4 Desember 2017).

Mitasasrini, Ni Made. 2015. "Penerapan Model Pembelajaran Think Talk Write untuk Meningkatkan Sikap Ilmiah Siswa Pada Mata Pelajaran IPA Kelas V SD". e-Jurnal PGSD Universitas Pendidikan Ganesha Mimbar PGSD, Vol: 3, No: 1. Tersedia pada : https://ejournal.undiksha.ac.id/index.php/JJPGSD/article/view/5629 (diakses tanggal 29 November 2017).

Putri Dewi Andriani, Siti Kamsiyati, Amir. 2016. Penerapan Model Pembelajaran Think Talk Write (Ttw) untuk meningkatkan Kemampuan menyelesaikan Soal Cerita Pecahan. Jurnal Didaktika Dwija Indria. Vol.4 No.7.

Resi Irmayati, Ali Imron, Suparman Arif. 2015. Pengaruh Model Think Talk Write (Ttw) Terhadap Hasil Belajar Ips Siswa. PESAGI (Jurnal Pendidikan dan Penelitian Sejarah). Vol 3, No 5.

Riastini, Putu Nanci. 2016. Pembelajaran IPA SD. Singaraja: Undiksha

Setya Ratna Dianuri, St. Y. Slamet, Jenny Indrastoeti Siti Poerwanti. 2016. Keefektifan Model Pembelajaran Think Talk Write (Ttw) Terhadap Kemampuan Menulis Cerita Ditinjau dari Minat Menulis pada Siswa Kelas IV Sekolah Dasar. Jurnal Didaktika Dwija Indria. Vol.4 No.7.

Shoimin. Aris. 2014. 68 Model Pembelajaran Inovatif dalam Kurikulum 2013. Yogyakarta: Ar-Ruzz Media.

Susanto, Ahmad. 2014. Teori Belajar \& Pembelajaran di Sekolah Dasar. Jakarta: Kencana.

Trianto. 2010. Model Pembelajaran Terpadu: Konsep, Strategi, dan Implementasinya dalam Kurikulum Tingkat Satuan Pendidikan (KTSP). Surabaya: PT Bumi Aksara.

Wardhany, Annisa Restu \& Gufron Amirullah. 2017. "Perbedaan Hasil Belajar Ilmu Pengetahuan Alam dengan Menggunakan Model Pembelajaran Think Talk Write dan Think Pair Share". Jurnal Inovasi Pendidikan Dasar, Vol: 2, No: 2, p-ISSN: 2477-3859, e-ISSN:2477-3581. Tersedia pada : http://jipd.uhamka.ac.id/index.php/jipd/article/view/52/22 (diakses tanggal 30 November 2017). 